\title{
Festival Culture, Metatheatre and Modernity in Karl Schönherr's Der Judas von Tirol
}

\author{
JUDITH BENISTON \\ University College London
}

\begin{abstract}
I
Catholicism and the Catholic festival culture of his native Tyrol feature repeatedly in the dramatic auvre of Karl Schönherr (1867-1943). Despite the predominantly critical tenor of his earlier works, in 1934 he proudly told an interviewer: 'Ich bin ein Mensch des katholischen Alpenlandes, im Tiroler Bauerndorf, gewissermaßen im Kirchturmschatten zur Welt gekommen' I am a product of the Catholic Alps, born in a Tyrolean farming village, in the shadow of the church tower, so to speak]. ${ }^{1}$ Growing up in this milieu, he claims to have formed a profound attachment to the biblical story of the Passion and fondly recalls his mother's vivid accounts of local 'Bauernpassionen' [peasant passion plays]. Directed by a curate and performed by the villagers 'mit naiver Begeisterung' [with naïve enthusiasm], these public celebrations of a shared religious and cultural identity served, according to Schönherr, as 'eine Ergänzung des kirchlichen Gottesdienstes und der Pfarrerpredigten' [a complement to church services and sermons, D, 639]. Although he claimed in 1934 that he had himself never seen a village passion play, dramatizations of the Passion feature in several of his plays. His most complex and challenging engagement with the trope comes in Der Judas von Tirol [The Tyrolean Judas], a historical 'Volksschauspiel' [folk drama] that is set during the aftermath of the Rebellion of 1809 and
\end{abstract}

\footnotetext{
${ }^{1}$ Karl Schönherr, Gesamtausgabe, ed. by Vinzenz K. Chiavacci jun., 3 vols (Vienna, 1967-74). The following abbreviations are used: Bühnenwerke (B); Lyrik und Prosa (L); and Bühnenwerke II, Briefe, Dokumentation, ed. by Franz Hadamowsky (D). Here D, 638-39, interview with the Neues Wiener Journal, 24 March 1934.
} 
incorporates a metatheatrical passion play. The text exists in three versions. Produced respectively in 1897, 1927 and the mid-1930s, they span Schönherr's literary career and collectively constitute an excellent vehicle for exploring his responses to his Tyrolean heritage in the light of the changing cultural and political climate.

The term 'metatheatre' was coined by Lionel Abel, in a 1963 study that endeavours, alongside the work of Eric Bentley, Martin Esslin and Peter Szondi, to construct a grand narrative of modernist drama. Abel argues that there is a mode of theatrical self-awareness and self-referentiality that has its roots in the Renaissance and Baroque - encapsulated in the adages that the world's a stage and life's a dream - and returned to prominence in modernist drama. He contends further that, whereas Shakespeare and Calderón celebrate and delight in the resulting ontological confusions, modernist metatheatre responds to the destabilization of traditional authority structures by introducing an element of self-critique, or even anti-theatricality. ${ }^{2}$ In focusing on Der Judas von Tirol, and especially on the 1927 version, which makes most sophisticated use of metatheatre, this article will therefore consider the play's relation to modernism - to both the strand of European modernism that Abel associates above all with Luigi Pirandello and to the more conservative but no less metatheatrical modernism of Schönherr's Austrian contemporaries Hugo von Hofmannsthal and Max Mell.

All three versions of Der Judas von Tirol are set in January 1810, when the village of St Leonhardt in Passeier is sheltering the fugitive folk hero Andreas Hofer from the occupying Franco-Italian forces and preparing to stage its annual passion play. The play-within-the-play is entirely fictional, but the story of Hofer's betrayal and arrest is based on historical events.

\footnotetext{
${ }^{2}$ Lionel Abel, Tragedy and Metatheatre. Essays on Dramatic Form, introd. by Martin Puchner (New York and London, 2003). Abel's argument is extended in Martin Puchner, Stage Fright. Modernism, Anti-Theatricality, and Drama (Baltimore, MD, 2002) and debated with in Against Theatre. Creative Destructions on the Modernist Stage, ed. by Alan Ackerman and Martin Puchner (Basingstoke, 2006).
} 
Schönherr is far from the first to dramatize them, with notable predecessors including Karl Immermann (1827), Berthold Auerbach (1850) and Karl Domanig (1886-87). ${ }^{3}$ While his Tyrolean contemporary Franz Kranewitter challenges patriotic consensus with a less than heroic depiction of the title figure in Andre Hofer (1902), the most distinctive features of Schönherr's approach are the decentring of his subject and the incorporation of metatheatre into a historical drama. The focus in Der Judas von Tirol is emphatically not on Hofer, who appears only in the final moments, but on Franz Raffl, the young farmhand who betrays him and is cast as Judas in the passion play.

In 1897 the play-within-the-play was part of the regional Naturalism that was to become a distinctive feature of Schönherr's work, especially in the early years of the twentieth century. Alongside the use of Tyrolean dialect and costumes supplied by a Tyrolean friend (D, 660), it is one of several folk elements that help to anchor Der Judas von Tirol in a specific time and place. The villagers' amateurishness provides local colour and comic relief, but the motif contributes little to the plot or to the characterization of Raffl and is dropped in the third act. Betrayal is motivated by a romantic attachment between the impoverished farmhand and innkeeper's daughter Burgl.

Der Judas von Tirol was Schönherr's first play to be staged. The premiere took place at the Theater an der Wien on 10 October 1897, while its author, who had qualified as a doctor in 1896, was working at a hospital in St Pölten. Although some reviewers saw potential, reception was at best mixed and at worst scathing. The Neue Freie Presse perceived 'entschiedene dramatische Begabung' [definite dramatic talent] but, like the Arbeiter-Zeitung, noted a reliance on predictable character types. ${ }^{4}$ A highly critical review in the Neues Wiener Journal was one of several

\footnotetext{
${ }^{3}$ See Ilse Wolfram, 200 Jahre Volksheld Andreas Hofer auf der Bühne und im Film (Munich, 2010).

${ }^{4}$ Anon., 'Theater an der Wien', Neue Freie Presse, Abendblatt, 11 October, 1897, p. 3; S., 'Theater an der Wien', Arbeiter-Zeitung, 11 October 1897, p. 4.
} 
to complain of inordinately long scene changes, attributing them to 'miserable Meiningerei' [a poor imitation of the Meiningen style], while the satirical magazine Kikeriki took up the motif of the Judaslohn [blood money] to declare the play 'nicht einmal fünfzehn Silberlinge werth' [not even worth fifteen pieces of silver]. ${ }^{5}$ According to Schönherr himself, one reviewer who knew that he was a doctor warned him not to give up the day job; and he claimed to have taken the advice of another, who urged him to burn the manuscript. ${ }^{6}$ Whether or not these stories are apocryphal, Schönherr only re-acquainted himself with his work in 1925, when the young researcher Josef Sahliger discovered a prompt copy amongst the archives of the Theater an der Wien, which had been incorporated into the recently established Theatre Collection of the Austrian National Library.

Whereas Der Judas von Tirol had only three performances in 1897, the substantially revised version, given its Viennese premiere at the Raimund-Theater on 8 March 1928, became one of the year's long-running hits. ${ }^{8}$ Staged by the Exl-Bühne, a much-lauded company from Innsbruck

\footnotetext{
${ }^{5}$ o. t.-b., 'Theater an der Wien', Neues Wiener Journal, 11 October 1897, p. 2; Anon., Kikeriki, 24
} October 1897, p. 3.

${ }^{6}$ 'Das Schicksal des “Judas von Tirol”. Ein Gespräch mit Karl Schönherr', Nenes Wiener Tagblatt, 8 April, 1928, pp. 15-16. Schönherr does not state which papers reviewed the play in these precise terms and I have found no corroborating evidence.

${ }^{7}$ For an account of the discovery, see Josef Sahliger, 'Viermal "Judas von Tirol”. Zum 70.

Geburtstag Karl Schönherrs am 24. Februar', Reichspost, 21 February 1937, pp. 19-20. Anton Bettelheim notes in Karl Schönherr. Leben und Schaffen (Leipzig, 1928), p. 145 that he subsequently located the censor's copy, now held in the Niederösterreichisches Landesarchiv in St Pölten.

\footnotetext{
${ }^{8}$ Primus-Heinz Kucher, 'Die Wiener Bühne(n) als moralische Anstalt? Das (Opern-)Theater-Jahr 1928', in Julia Bertschik, Primus-Heinz Kucher, Evelyne Polt-Heinzl and Rebecca Unterberger,
} 
who specialized in Tyrolean folk drama and had a well-established collaboration with Schönherr, it reached seventy-five performances by late May 1928, was only taken off in June because of pre-arranged guest performances and returned in the autumn. ${ }^{9}$ With Eduard Köck playing the title role to great acclaim, the play established itself as a repertoire staple for the Exl-Bühne. It has also been filmed several times, first in 1933 (directed by Franz Osten). The new text was published by Staackmann in Leipzig in 1927 and forms the final play in the four-volume Gesammelte Werke [Collected Works] issued by Speidel later that year to mark Schönherr's sixtieth birthday. ${ }^{10}$

In this revised version, Der Judas von Tirol is a radically modern re-imagining of historical events that exploits the vogue for metatheatre but stands in critical relation to other aspects of the interwar cultural climate. Comparisons with Pirandello, whose work was first staged in Vienna in 1924, can readily be made, even though, as one reviewer observed, in Der Judas von Tirol shifts between theatrical play and historical reality take place 'nicht auf pirandelleske, heißt auf intellektuelle Art, sondern eindringlicher: als ein seelischer Prozeß’ [not in a Pirandellesque that is, an intellectual - manner, but more poignantly, as a psychological process]. ${ }^{11}$ Ontological confusion is not an end in itself but generates modern psychological insights. In the words of another reviewer, it was 'ein kühnes Experiment, vor einer kleinen Welt von Kapellen, Herrgottswinkeln und Kruzifixen an die Stelle des Dogmas, der biblischen Wahrheit, die

1928: Ein Jahr wird besichtigt (Vienna, 2014), pp. 201-37 (especially pp. 209-11). Before its Viennese premiere, the revised Der Judas von Tirol was tried out in Graz and Cologne.

${ }^{9}$ See Eckehart Schmidl, Der Traum vom Volkstheater. Die Geschichte der Exl-Bübne (1902-1956)

(Innsbruck and Vienna, 2013), especially pp. 102-05.

${ }^{10}$ References to the 1927 version of Der Judas von Tirol are to Karl Schönherr, Gesammelte Werke, 4 vols (Vienna, 1927), IV, abbreviated as GW4.

${ }^{11}$ r. g., 'Schönherrs “Judas von Tirol”, Der Morgen, 12 March 1928, p. 6. 
Psychoanalyse zu setzen' [a bold experiment, to set psychoanalysis in the place of dogma and biblical truth, against a background of chapels, household shrines and crucifixes]. ${ }^{12}$ The experiment was all the more radical because it subverted the expectations associated with historical folk drama as a genre and with the Tyrolean setting. In order to access this aspect of the play's modernity, my reading will be informed not only by Abel's work but also by Freud's 'Das Unheimliche' [The Uncanny, 1919] and by cultural anthropologist René Girard's classic study of The Scapegoat (first published in French in 1982).

Notwithstanding its considerable success, Schönherr made further revisions to Der Judas von Tirol in the mid-1930s, almost certainly prompted by plans to stage the play at the Burgtheater, by then under the control of the Austrofascist state. ${ }^{13}$ Although these fell through, the new version was performed by the Exl-Bühne at the Wiener Bürgertheater in February 1937 to mark his seventieth birthday. ${ }^{14}$ The changes are relatively slight but effect a subtle shift

\footnotetext{
${ }^{12}$ f. 1., 'Karl Schönherrs “Der Judas von Tirol”", Neues Wiener Journal, 9 March 1928, pp. 10-11 (p. $10)$.

${ }^{13}$ Schönherr's papers in the Österreichisches Theatermuseum in Vienna include an unpublished letter of 28 March 1935 in which Burgtheater director Hermann Röbbeling requests a copy of Der Judas von Tirol with a view to staging it in the following season. Schönherr later protests that the book has been gathering dust in the Burgtheater archives for more than a year, even though it would be suitable for performance there, with 'ein paar allfällige ganz kleine Striche' [possibly a few minor cuts, D, 645].

${ }^{14}$ On the 1937 production, see Sahliger, 'Viermal “Judas von Tirol”'. The three-volume Gesamtausgabe [Complete Edition, 1967-74] presents the 1897 text alongside what is billed as the 1927 version but in fact incorporates the revisions that were made in the mid-1930s and are outlined by Sahliger. This text brings the dialect closer to standard German than either of its predecessors.
} 
towards a form of modernism that is more affirmative of the Catholic heritage and more in tune with the new cultural climate. They also allow Der Judas von Tirol to sit more easily alongside Schönherr's most significant new plays of the 1930s, the Passionsspiel [Passion Play, 1933] and Die Fahne weht [Flying the Flag, 1937], both of which engage once again with the passion play trope.

\section{II}

In the 1927 version of Der Judas von Tirol, the metatheatrical passion play is rehearsed in the first act, reflected upon in the second and re-enacted by Raffl in the third. It becomes the key means by which Schönherr contrives to arouse sympathy for the traitor and to build up an unflattering picture of the peasant community that oppresses, belittles and ultimately excludes him. As in the original play of 1897 , the performance tradition is depicted not as part of the village's religious life but as a hollow folk custom kept going by the distribution of 'Spielgeld' [payments for the actors, GW4, 269]. Directed not by a clergyman but by the reluctant village schoolmaster, it is a recurrent source of conflict: 'So wie s zum Passionsspielen kommt, geht jedsmal der Streit an!' [Whenever the passion play comes around, that's when the trouble starts!, GW4, 261]. Raffl is indeed first seen making off with the 'Christusmantel' [Christ's robe, GW4, 266], claiming the role on the basis of similarities between Christ's modest circumstances and his own. That casting is out of the question because tradition demands that Christ should be played not by a landless farmhand such as Raffl but by 'ein erbgsessner Baurnsohn' [a son who will inherit a family farm, GW4, 267]. Raffl has to play Judas. Rather than transcending everyday life, the passion play reproduces social normativity, as a repressive social hierarchy based on property and parentage is mapped onto its configuration of characters. As Raffl pointedly observes in the final version: 'Wer Geld hat, hat auch den Heiligenschein' [Anyone who has money gets the halo to go with it, B, 686]. The rural underclass are expected to play a set of roles collectively termed 'die 
Verdammten’ [the damned]; their lot consists in ‘die härteste Arbeit, die schlechtesten Brocken in der Schüssel, die größten Lumpen beim Passionsspiel' [the hardest work, the worst morsels in the pot, the meanest rags in the passion play]. The exchanges in which Raffl tries to refuse the 'Judasmantl' [Judas's coat, GW4, 268] and the discrimination that it perpetuates strongly recall the recalcitrance of the Beggar in the framing play of Hofmannsthal's Calderón adaptation Das Salzburger Große Welttheater [The Salzburg Great Theatre of the World, 1922]. Whereas the Baroque theatrum mundi is metaphysically underpinned, and Hofmannsthal's Beggar is talked round by an Angel who offers glimpses of redemption within and beyond the role, Schönherr's world offers no such comfort. In what Raffl ruefully calls 'das Bauernevangel' [the farmers' gospel, GW4, 269], the iniquities of the earthly sphere are unapologetically projected onto the biblical narrative.

As a result of being obliged to play the archetypal traitor, Raffl becomes one. $\mathrm{He}$ gradually loses the ability to distinguish between role and reality in a process of on-stage transformation that is psychologically complex and makes fascinating theatre. Schönherr hereby subverts another Baroque motif beloved of conservative modernists, that of the actor who is converted to Christianity by playing a Christian on stage. It is the basis of Jakob Bidermann's Philemon Martyr (1616), Lope de Vega's Lo Fingido Verdadero [The Feigned Truth, 1621] and Jean de Rotrou's Le véritable Saint-Genest [The Real Saint Genesius, 1646]. ${ }^{15}$ The idea that the ontological confusion generated by impersonation can precipitate conversion (or, at the very least, a change of heart) is taken up in several of Mell's plays, including Das Apostelspiel [The Apostles Play, 1923] and Das Nachfolge Christi-Spiel [The Play of Following Christ]. ${ }^{16}$ Premiered at the Burgtheater on 21

\footnotetext{
${ }^{15}$ Mary Ann Frese Witt, Metatheater and Modernity. Baroque and Neobaroque (Madison, WI, 2013), especially Chapter 1: 'From Saint Genesius to Saint Genet. Actors, Martyrs, and Metatheater' (pp. 19-51).

${ }^{16}$ See Judith Beniston, 'Max Mell in the First Republic: The Acceptable Face of Catholic Drama?', in From Perinet to Jelinek. Viennese Theatre in its Political and Intellectual Context, ed. by W.E.
} 
January 1928, Das Nachfolge Christi-Spiel stands alongside Der Judas von Tirol as the other notable non-musical hit of a theatre season that was characterized by both traditionalism and turbulence. ${ }^{17}$ Set in the sixteenth or seventeenth century, against a background of social unrest in the aftermath of war that suggests parallels with the upheavals of 1918/19, it features a pious 'Schloßherr' [landowner] who builds a replica Calvary on his estate. He is awaiting delivery of the Christ statue that will complete the ensemble when his estate is attacked by vicious marauders who nail him to the empty cross, in an act of class hatred and mindless bloodlust. Rescued in the nick of time but barely alive, the landowner has been profoundly affected by this enforced imitatio Christi and pleads for his tormentors to be granted clemency. When his pleas fall on deaf ears he prays for a miracle and receives one in that he promptly falls down dead, in what Alfred Polgar describes as 'eine Art Kurzschluß [...] zwischen heiliger und weltlicher Passion' [a kind of short circuit between sacred and secular passion]. ${ }^{18}$ Although the landowner foregrounds his humanity, saying 'Ich bin ein Mensch, kann nur wie ein Mensch erlösen’ [I am a Man, I can only redeem as a Man], the play's outcome is susceptible to interpretation both in secular, psychological terms and via the Catholic doctrine of mystical substitution. ${ }^{19}$ Thus, in the spring of 1928, the Viennese public was simultaneously offered a Nachfolge Christi-Spiel and what one might term by analogy a 'Nachfolge Judas-Spiel', the former celebrating a conservative Catholic legacy, the latter asking awkward questions of it. Together they illustrate one of the major fault lines of interwar Austrian culture but also betray an aesthetic affinity that cuts across it.

Yates, Allyson Fiddler and John Warren (Oxford, 2001), pp. 179-90 and Judith Beniston, “'Der Wiener aus Hofmannsthal": The Making of Max Mell's Das ApostelspieP, Modern Language Review, 104 (2009), 472-98.

${ }^{17}$ Kucher, 'Die Wiener Bühne(n) als moralische Anstalt?', especially pp. 206-09.

${ }^{18}$ Alfred Polgar, 'Theater. Das Nachfolge-Christi-Spiel', Der Morgen, 23 January 1928, p. 4.

${ }^{19}$ Max Mell, Prosa. Dramen. Verse, 4 vols (Munich, 1962), I, 312. 
Like Mell's play, Schönherr's Der Judas von Tirol features a short circuit. It is triggered when Raffl reluctantly agrees to rehearse the scene in which Judas demands his thirty pieces of silver. Initially delivering the lines in a schoolboy monotone, he is sent out to repeat his entry, 'daß du ein bissel in den Judas seine Haut einikriechst' [so that you get under that Judas's skin a bit, GW4, 273]. As Martin Puchner writes, 'modern theatre becomes metatheatre when there is an accident in the machinery of the play, when something goes wrong, or when the play simply no longer progresses' ${ }^{20}$ In Der Judas von Tirol the rehearsal is interrupted by the arrival of a French officer and his entourage. Raffl enters to deliver his line: 'Hohe Priester und Soldaten, ich hab nach Wunsch ...' [High priests and soldiers, I've done as you bid me ...] and hears in response the formal announcement that a price of two hundred ducats has been placed on Hofer's head. The stage direction indicates that he follows this unexpected turn of events 'in steigender Erregung' [with mounting agitation, GW4, 277]. When the rehearsal resumes, the stage direction notes that Raffl is 'in seinem Spiel und Gehaben beinahe unheimlich zum Vorteil seiner Rolle verändert' [his acting and behaviour have changed to the benefit of his role, in a manner that is almost uncanny, GW4, 278]. Furthermore, when he receives the thirty pieces of silver, he makes the Freudian slip of counting 'Zehn, zwanzig, fufzig, hundert!' [Ten, twen'y, fifty, hundred!, GW4, 279]. Although the schoolmaster is delighted by the improvement, the stage directions signal that the audience is intended to find Raffl's performance disturbing, in ways that invite a reading informed by Freud's thinking on the uncanny.

Theologians have long debated the motivation of the biblical Judas, which is far from clear in the gospels' twenty-two references to him: does it lie in human greed, as the blood money would seem to suggest, or perhaps in political disappointment, as Judas's indignation at the anointing of Jesus (John 12.1-7) might imply? And is he caught up in the eternal battle between good and evil, God and the Devil, and therefore not entirely responsible for his

\footnotetext{
${ }^{20}$ Puchner, Introduction to Abel, Tragedy and Metatheatre, p. 18.
} 
actions ${ }^{21}$ All the gospels make clear that Jesus knows in advance both the suffering that awaits him and the part that Judas will play in those events. This prophetic tone serves to underline the theatricalized nature of the passion, and in the 1930s version of Der Judas von Tirol Schönherr has Raffl read out the key passage from Matthew's account of the Last Supper (Matthew 26. 20-25, $\mathrm{B}, 686)$. Whereas thirty pieces of silver bought only a burial field, the price on Hofer's head is enough for a small farm, and the historical Raffl, a dissolute and impoverished neighbour of Hofer, was undoubtedly motivated by money. Schönherr had been warned by the prominent Viennese journalist Zacharias Konrad Lecher, who read a draft of Der Judas von Tirol in 1896, that audiences would have no sympathy for the traitor if he were merely a 'Geizkragen' [skinflint, D, 562]. He responded by motivating the betrayal in the first version by means of a romantic subplot and subsequently in more modern psychological terms.

Raffl's initial response to the metatheatrical short circuit between the betrayal of Jesus and that of Andreas Hofer is a form of cognitive dissonance. Just as Freud defines the uncanny as 'jene Art des Schreckhaften, welche auf das Altbekannte, Längstvertraute zurückgeht' [that class of the frightening which leads back to what is known of old and long familiar], so Raffl's uncannily improved performance can be read as the product of a longstanding, repressed and forbidden impulse - to take revenge on his oppressors and improve his finances - that simultaneously attracts and repulses him. ${ }^{22}$ Ontological levels are blurred from the outset by his

\footnotetext{
${ }^{21}$ For a historical and cultural biography of the biblical traitor, see Peter Stanford, Judas. The Troubling History of the Renegade Apostle (London, 2015). Chapter 2 surveys the presentation of Judas in the gospels (pp. 37-61).

${ }^{22}$ Sigmund Freud, 'Das Unheimliche', in Studienausgabe, ed. by Alexander Mitscherlich et al., 10 vols (Frankfurt a.M., 1969-75), IV, 244; 'The Uncanny', in The Standard Edition of the Complete Psychological Works of Sigmund Freud, trans. and ed. by James Strachey et al., 24 vols (London, 195374), XVII, 220.
} 
insistence on using his own greatcoat for the rehearsal and putting the blood money in his own knapsack because they are 'heimischer' [more homely, GW4, 273], and he increasingly struggles to distinguish between the theatrical role of Judas Iscariot and 'ein Judas' as a generic term for a traitor. The stage directions refer to Raffl as 'verwirrt' [confused, GW4, 279] and as trying to resist his own train of thought. At the end of the first act, he indeed refuses to play Judas with a new vehemence, declaring 'I will nit! [...] Mier graust!' [Won't! 'S too horrible!, GW4, 280]. For Freud 'Grausen' is a characteristic response to the uncanny, as in the final stanza of Friedrich Schiller's 'Der Ring des Polykrates' [The Ring of Polycrates, 1797], when the guest responds 'mit Grausen' [in horror] to his host's seemingly unnatural good fortune. ${ }^{23}$ Whereas the guest flees, for fear of being swept up in his host's downfall, Raffl's attempt to extricate himself proves futile as the other performers merely dismiss his fears as stage fright.

In all three versions of Der Judas von Tirol the question of money, which is so central to the biblical characterization of Judas Iscariot, only comes to the fore in the second act. Once the passion play has been performed and Raffl has stolen the show, he demands that, as the best actor, he should receive a larger share of the 'Spielgeld'. The necessity of evil is a conundrum that has troubled theologians since St Augustine, and in the second and third versions of the play, Schönherr has Raffl argue provocatively that without Judas's betrayal the Passion would not happen: 'Du, Christus! Wenn i dich nit verrat, nacher hast du gleich ausgspielt und das ganze Passionsspiel ist für!' [Look here, Christ! If I don't betray you, then you won't have much of a part to act and that'll be it for the passion play!, GW4, 288]. The villagers are disconcerted by both by this renewed challenge to tradition and Raffl's unexpected thespian talent. In the 1927 text Burgl speaks 'noch ganz unter einem starken, beklemmenden Eindruck' [still under the spell of a powerful, disquieting impression], created by a performance that she sums up as 'zum Fürchten!' [terrifying!, GW, 282]. Others express a combination of admiration and unease: 'Ja,

\footnotetext{
${ }^{23}$ Freud, 'Das Unheimliche', p. 261; 'The Uncanny', p. 239.
} 
der Judas! Der hat s getroffen! Ja, der wohl! Da ist s einem kalt über den Buckl gloffen!' [What about Judas! He nailed it! Really did! Sent a shiver right down your spine!, GW4, 285]. As Raffl's demands are rejected by the community and he becomes increasingly insistent, Schönherr again conjures up the uncanny. The climactic assertion 'Ich bin der Judas!' [I am Judas!] is accompanied by the stage directions 'Sich gewaltig mit unheimlich glühenden Augen gegen die Anwesenden aufreckend' [Raising himself to his full height and confronting the others with an uncanny fire in his eyes] and 'Die Anwesenden weichen unwillkürlich vor Raffl zurück' [The others recoil involuntarily from Raffl, GW4, 292]. Just as the biblical Judas is possessed by the devil, so Raffl evolves into a demonic figure.

In 'Das Unheimliche' Freud characterizes the disruption of stable selfhood that is triggered by the uncanny with reference to the concept of the Doppelgänger or double. A relationship is formed 'durch Überspringen seelischer Vorgänge von einer dieser Personen auf die andere - was wir Telepathie heißen würden -, so daß der eine das Wissen, Fühlen und Erleben des anderen mitbesitzt' [by mental processes leaping from one of these characters to another - by what we should call telepathy -, so that the one possesses knowledge, feelings and experience in common with the other]. Freud's image of telepathy is more fanciful than Polgar's 'short circuit' but likewise conveys the sense of a sudden and unintended connection. Freud's subsequent observation that it may result in 'die beständige Wiederkehr des Gleichen' [the constant recurrence of the same thing $]^{24}$ is reflected in the third act of Der Judas von Tirol, as Raffl leads the French troops to Hofer's hiding place in a seemingly compulsive reprise of his stage role, repeating Judas's lines, prompting his interlocutor for cues and counting the two hundred ducats into his bag as he had done the thirty pieces of silver.

Freud's 'Das Unheimliche' theorizes the uncanny in essentially non-religious, ahistorical terms, as a province of aesthetics. It is, however, a modern, secular concept and therefore has a

\footnotetext{
${ }^{24}$ Freud, 'Das Unheimliche', p. 257; ‘The Uncanny', p. 234.
} 
history. ${ }^{25}$ Indeed he concedes in 'Die Zukunft einer Illusion' [The Future of an Illusion, 1927] that a pre-modern, religious sensibility may feel 'heimisch im Unheimlichen' [at home in the uncanny $].{ }^{26}$ Schönherr's stage directions presume that the offstage audience, like that on stage, does not. The only exception is Raffl's foster-father, Martl, a kindly farmhand with a simple but sincere Christian faith. When Raffl calls out 'es hat mich, es hat mich' [it's got me, it's got me, GW4, 293], the old man urges him to pray. However, by using the impersonal 'es', Schönherr allows his text to hover between the sacred and the secular, simultaneously evoking the diabolic and the Freudian unconscious, as Raffl realizes that he is too much in the grip of his Doppelgänger to find solace in the Lord's Prayer.

The villagers deal with their profound unease by finding reasons to define Raffl as 'unheimlich' in the sense of being 'unhomely' and to exclude him from the Tyrolean homeland. In so doing they enact a collective persecution that has its deep roots in the heightened social tensions of living in an occupied territory and bears many of the stereotypical features identified in Girard's The Scapegoat. ${ }^{27}$ Following an exchange of reciprocal insults, defined by Girard as a typical prelude to persecution, an exclusionary narrative is generated by Schmiedkathl, the elderly village midwife, who conveniently recalls that Raffl was a foundling left by the roadside and therefore probably not the child of local parents - they may have been gypsies or even French. By identifying him as an outsider she singles him out for persecution. Girard observes that

\footnotetext{
${ }^{25}$ See Nicholas Royle, The Uncanny (Manchester, 2003), pp. 20-23.

${ }^{26}$ Sigmund Freud, 'Die Zukunft einer Illusion', in Studienausgabe, ed. by Mitscherlich et al., IX, 151; 'The Future of an Illusion', in The Standard Edition of the Complete Psychological Works of Sigmund Freud, trans. and ed. by Strachey et al., XXI, 17.

${ }^{27}$ René Girard, The Scapegoat, trans. by Yvonne Freccero (London, 1986), especially Chapter 2, 'Stereotypes of Persecution'. Interestingly, Stanford suggests that Judas is made a scapegoat in the gospels. See Stanford, Judas, pp. 38, 49-50.
} 
victims of persecution are often accused of crimes that attack the foundations of social or religious order. ${ }^{28}$ Der Judas von Tirol follows this pattern when Schmiedkathl points out that Raffl's demand for greater remuneration will disadvantage 'die armen Kinder und Weiber' [the poor women and children, GW4, 290], thereby transgressing the taboo that the weakest and most defenceless members of society must be protected.

The midwife has the superstitious habit of predicting the fate of every child she delivers on the basis of its distinguishing features at birth, and repeatedly recalls an ominous 'Haarwirbl' [whirl of hair, GW4, 265] on the infant Hofer's head. However irrational or ridiculous her predictions may be - a tonsure-like patch on a newborn's scalp points to a future cardinal (GW4, 305) - they nevertheless constitute a sign system reinforcing the impression that Der Judas von Tirol is what Abel calls 'a theatre piece about life seen as already theatricalized'. ${ }^{29}$ In the first and final versions, the midwife concludes her scapegoating of Raffl by recalling a snakelike birthmark on his neck and proposing two responses that Girard identifies as stereotypical. In the 1897 text she stresses his capacity to cause harm and advocates avoidance: 'So an' Menschen soll man nit aufzügeln - so ein' soll man aus dem Weg gehn wie an' giftigen Wurm' [You shouldn't raise a child like him - you should steer clear of him like you would a venomous snake, D 128]. In the mid-1930s the warning becomes a direct incitement to violence: 'So einem soll man den Kopf zsammtreten wie einem giftigen Wurm!' [You should stamp on his head like you would a venomous snake!, B, 703]. Once Raffl is thus identified as a threat, the villagers become a mob. He is barred from playing even Judas, the traitor's red beard is torn up, he is sacked by his employer and (in 1927 only) ordered out of the village.

Critical responses to Schönherr's inclusion of the foundling motif, which has no historical basis, differed widely. Felix Salten dismissed it as 'schwach (und 'völkisch”)' [weak

\footnotetext{
${ }^{28}$ Girard, The Scapegoat, p. 15.

${ }^{29}$ Abel, Tragedy and Metatheatre, p. 134.
} 
(and völkisch)], presumably objecting to the introduction of racist nationalism into a play otherwise exploring more mutable notions of selfhood. By contrast, Erwin H. Rainalter endorsed the persecutors' narrative, declaring the foundling Raffl to be innately incapable of patriotism. ${ }^{30}$ It is my contention that, by exposing the mechanism of scapegoating at work in the community, Schönherr not only generates sympathy for the victimized Raffl, but also presents the village community in a way that should militate against the reception of Der Judas von Tirol as a patriotic festival play. As Salten notes: 'Hier sind statt der Schollenwurzel die Wurzeln der Internationale bloßgelegt' [What are laid bare here are not roots extending into the local soil but the roots of the Socialist International]. ${ }^{31}$ Rather than celebrating the solidarity of the village community, the play draws attention to social dynamics that threaten it and, in the twentieth century, fuel class conflict. A review in Das kleine Blatt goes further: 'Erst in einer Gemeinschaft von Gleichen, die nicht mehr Herren und Knechte kennt, wird es ein allumfassendes, brüderliches Zusammengehörigkeitsgefühl geben, an dem jede fremde Knechtschaft zuschanden wird' [Only in a community of equals, where there are no more masters and servants, will there be a fully inclusive sense of brotherly solidarity that will withstand any form of foreign servitude]. ${ }^{32}$ Whether such a utopian message can be derived from the play is debatable, but it certainly retains the compassion for social suffering that is characteristic of Schönherr's early Naturalism.

\footnotetext{
${ }^{30}$ Felix Salten, 'Schönherr-Premiere. "Der Judas von Tirol.” - Raimund-Theater', Neue Freie Presse, 10 March 1928, pp. 1-3 (p. 2); Erwin H. Rainalter, 'Der Judas von Tirol', Neues Wiener Tagblatt, 9 March 1928, pp. 8-9 (p. 8).

${ }^{31}$ Salten, 'Schönherr-Premiere', p. 3.

${ }^{32}$ Johann H., 'Der Fluch der Knechtschaft. “Der Judas von Tirol.” Raimund-Theater', Das kleine Blatt, 9 March 1928, pp. 9-10.
} 
In Der Judas von Tirol as historically, Hofer refuses to leave his homeland: "Im Land bin i gwachsen und da im Land bleib i! Und den tirolischen Boden verlassn tue i halt gar und gar nie!"” ['I was raised here and here I stay! And I'm not leaving Tyrolean soil, no, not never!']. In this assertion of local patriotism Raffl hears only the voice of 'der Erbgsessne', the farmer who owns his own land: 'Dös vom tirolischen Boden geht mier gwaltig zu Herzen. [...] Weil i halt selber kein Fingerbreit hab!' [That guff about the Tyrolean soil is all very touching. B'cause me, I don't have so much as an inch of it!, GW4, 297-98]. Although Raffl has no personal grudge against Hofer, for him the folk hero comes to embody an oppressive landowning class. He betrays him partly as a result of complex processes of ontological confusion and partly in an act of revenge on the community that has belittled and expelled him. At the instigation of Schmiedkathl, he comes to perceive the repeated assertion that 'no Tyrolean' knows Hofer's whereabouts as explaining, or even justifying, his actions.

III

Focusing primarily on the 1927 version of Der Judas von Tirol, this reading of the play has drawn attention to its metatheatrical challenge to cultural and political conservatism and its strikingly modern emphasis on individual and collective psychology. Notwithstanding these features, in 1928 the Viennese production was welcomed in many quarters as a celebration of Tyrolean resilience in adversity and as a largely uncritical perpetuation of the Andreas Hofer myth. ${ }^{33}$ Thirty years earlier, when Tyrolean history was perceived as having little broader political relevance and

\footnotetext{
${ }^{33}$ On Schönherr's depictions of Andreas Hofer, see Marijan Bobinac, 'Gaismair - Hofer Jeanne d'Arc. Zur Figur des scheiternden Rebellen im historischen Volksstück um 1900 und um 2000', Zagreber Germanistische Beiträge, Beiheft 8 (2004), 101-22 (pp. 110-14).
} 
Der Judas von Tirol was a more conventional folk drama, the Neue Freie Presse had suggested that the play 'wäre mehr für den Tiroler Boden, etwa im Rahmen eines Festspieles, geeignet' [would be more suited to Tyrolean soil, perhaps as part of a festival event] $\cdot^{34}$ In the First Republic, by contrast, the loss of South Tyrol under the terms of the Treaty of St Germain-en-Laye created the conditions for a sympathetic supraregional reception, just as Italy's entry into the First World War had done for Schönherr's first successful Hofer drama, Volk in Not [National Distress, 1916]. ${ }^{35}$ This reception owed less to the logic that if Raffl is Judas, then Hofer is Christ, or indeed to the villagers' self-pity, than to the extratextual factor that the premiere came only a few days after Benito Mussolini had responded scornfully to Austrian demands that Italy should respect the traditions and identity of South Tyrol. ${ }^{36}$ This topicality, which Schönherr himself welcomed in an interview with Die Stunde (D, 629-30), was applauded in many reviews, with Salten, for example, commending the play's 'zweifachen Widerhall' [dual echo] and Rainalter declaring 'Volk in Not - vor hundert Jahren wie heut!' [National distress - a hundred years ago and now! ${ }^{37}$ While Schönherr's opportunistic response is in line with his vehement opposition to the terms of the peace treaty, unmistakably asserted in the leading article "Freiheit durchleuchtet

\footnotetext{
${ }^{34}$ Anon., 'Theater an der Wien', p. 3.

${ }^{35}$ On changing perceptions of Schönherr's regionalism, see Sigurd Paul Scheichl, 'Die Rückkehr in die Regionalliteratur. Karl Schönherr und Franz Kranewitter', in Raum - Region - Kultur.

Literaturgeschichtsschreibung im Kontext aktueller Diskurse, ed. by Marjan Cescutti, Johann Holzner and Roger Vorderegger (Innsbruck, 2013), pp. 95-105.

${ }^{36}$ Mussolini's speech was widely reported in the Austrian press on 4 March 1928.

${ }^{37}$ Salten, 'Schönherr-Premiere', p. 1; Rainalter, 'Der Judas von Tirol', p. 9.
} 
die Welt"' ['Liberty Enlightens the World'], ${ }^{38}$ the reviews of Der Judas von Tirol highlight the extent to which the socio-political context of performance can colour the reception of a literary work.

Throughout his career Schönherr was extremely sensitive to the question of topicality. Beginning with the second version of Sonnwendtag [Midsummer's Day, 1902], published in 1905, he developed the habit of rewriting (and sometimes retitling) plays with which he was dissatisfied, either because they had not been entirely successful or because he perceived them to have lost contemporary relevance. ${ }^{39}$ Although the 1927 version of Der Judas von Tirol had fared markedly better than its forerunner and revived Schönherr's fortunes in the theatre, he revised it again at some point between 1935 and early 1937, presumably in an attempt to improve its chances of being accepted at the Burgtheater. What is most striking about this final revision is that, without compromising the play's social criticism or its acuity as a portrait of individual and group psychology, he makes it more sympathetic towards Catholicism and more respectful in its depiction of Catholic festival culture.

Schönherr achieves this shift of emphasis, first, by adjusting the characterization of Raffl and, second, by generating comedy in a less irreverent manner. Raffl remains angry and socially disaffected but in this version also has genuine piety. He is introduced as a wistful figure who finds solace in the Bible and wants to play Jesus because he identifies with his suffering and forbearance. He responds to Burgl's comment that his performance as Judas sent a shiver down

\footnotetext{
${ }^{38}$ Karl Schönherr, “Freiheit durchleuchtet die Welt”, Neue Freie Presse, 4 March 1923, p. 1. The title reproduces the official name of the Statue of Liberty. The text is reprinted in the Gesammelte Werke (1927) as a preface to the protest play Hungerblockade 1919 (GW4, 200-01).

${ }^{39}$ A table of Schönherr's revisions presented in the Gesamtausgabe distinguishes eight versions of Sonnwendtag, outdone only by the fifteen versions and eight new titles of Das Königreich [The Kingdom, D, 730-35].
} 
her spine by telling her 'du weißt ja nit, wie ich den Christus gmacht hätt' [you don't know how I'd have played Christ, B, 707]. With a metatheatrical self-consciousness that is almost Brechtian, the traitor draws attention to society's part in determining human behaviour and to the other roles he might have played - in the passion play, in the community and (in a tentative reinstatement of the romantic subplot) vis-à-vis Burgl herself.

In all three versions of Der Judas von Tirol, the play-within-the-play is its main source of comedy. In 1897, it features prominently in two scenes. In the first the exasperated schoolmaster gives directorial notes to the villagers playing the minor roles: a spear should not be carried in the same manner as a pitchfork; Roman soldiers wear helmets not woolly hats; and Pontius Pilate certainly did not smoke a pipe (D, 119-20). Such injunctions make clear that the metatheatrical passion play has all the traditional weaknesses and involuntary comedy of more secular amateur dramatics. In the second, post-performance scene, the schoolmaster berates the farmhand playing the Roman soldier Longinus, who has wounded the villager playing Jesus by jabbing him in the side with a spear at the crucifixion rather than puncturing a strategically placed bag of pig's blood. As Schönherr reported to his friend Josef Pöschl, the censor licenced Der Judas von Tirol for performance in 1897 on the condition that these scenes would be 'geschwächt' [toned down, $\mathrm{D}, 660]$.

Unfettered by censorship, the 1927 version is even more irreverent. Schönherr pokes fun at the naïve literalism of the rustic staging - the cock that crows thrice is a small boy in a feathered cap, and Mary's halo is the work of a local tinsmith - and has Longinus aim badly because he is distracted by Mary Magdalene's cleavage. Here, the villager playing Jesus, who is characterized by Raffl as 'der größte Raufhansl im ganzen Pseirertal' [the worst hothead anywhere in the Passeier valley, GW4, 266], comes to blows with the offending farmhand. Burgl too loses her temper with an inebriated performer, prompting her father to observe that 'Was der Raffl vom Judas zu viel hat, hat die Burgl von der Maria zu wenig!' [If Raffl has too much of Judas, then Burgl has too little of Mary!, GW4, 283]. Reviewing the Viennese production, Hans 
Brečka of the Catholic Reichspost, a strong supporter of Catholic amateur dramatics (the so-called Laienspiel movement), complains that 'die Spässe, die hier von den Passionsspielern im Kostüm ihrer Rollen, ja manchmal mit dem Sinn dieser Rollen getrieben werden, sind stellenweise von einer Derbheit, die religiöses Empfinden verletzt. [...] Ein Christileidenspiel ist für gottesfürchtige Landleute wahrhaftig kein Anlaß für possenhaft derbes Gezänk' [the jokes that are made here by the villagers taking part in the passion play, in costume, sometimes even making fun of their roles, are at times so coarse as to offend religious sensibilities. For Godfearing country folk a dramatization of Christ's Passion is truly no place for coarse, farcical squabbling $].{ }^{40}$ At the censor's insistence, in 1897 the key biblical figures, and with them the spiritual core of the passion play, were untouched by broad comedy, whereas the 1927 version is less selective in its irreverence.

Revising Der Judas von Tirol again in the mid-1930s, Schönherr removes the coarse humour, especially where it impinges on the roles of Jesus and Mary. Effectively addressing Brečka's criticisms, he expunges all reference to the crucifixion mishap, leaving only the schoolmaster's exasperation and the harmless incompetence of the village inebriate - a prudent decision as Brečka wielded considerable power over the Viennese theatre scene from 1934 to 1938, as director of the Österreichische Kunststelle [Austrian Cultural Agency]. The passion play remains a somewhat secular affair, rather than a spiritually enriching experience that takes the villagers out of their everyday lives; but that ideal, to which Raffl paradoxically aspires, is treated with considerable respect.

The 1927 version of Der Judas von Tirol ends on a moment of triumph for Raffl: 'Thr Großkopfetn! Habt s gmeint, mich laßt s nimmer mittuen, gelt? Jetz hab i halt doch noch eimal mitgspielt: ich, der Knecht!' [You smart alecks! You thought you'd always be able to stop me joining in, didn't you? But now I've really played a part, me, the farmhand!, GW4, 315]. The

\footnotetext{
${ }^{40}$ B. [Hans Brečka], 'Der Judas von Tirol', Reichspost, 10 March 1928, pp. 1-2 (p. 2).
} 
traitor's exultant tone echoes the biography of the historical Franz Raffl who, following the events of January 1810, resettled in Bavaria, lived a further twenty years and fathered numerous children. In a significant departure from historical fact, the final version of Schönherr's play has Raffl pull out his Bible and read Matthew 27. 3-5: 'und als er sah, was er angerichtet hatte, da reute es ihn, und er ging hin ... und erhängte sich!' [and when he realized what he had done, he was full of remorse and went away $\ldots$ and hanged himself!, $B, 718]$. The final stage direction indicates that Raffl gets up and walks towards a tree. Although one might suggest that the farmhand continues to play his metatheatrical role because the community has left him no other, the biblical quotation closes the play on a note of political quietism, containing Raffl's rebellion, just as Hofmannsthal contains that of the Beggar in Das Salzburger Große Welttheater.

Whereas in the 1897 version of Der Judas von Tirol the play-within-the-play did little more than legitimize Schönherr's choice of title, in 1927 he drew on the vogue for metatheatre to produce an innovative re-imagining of Hofer's betrayal that is simultaneously a social and an aesthetic critique of Catholicizing festival theatre and of idealized treatments of the Alpine peasantry. Although the contemporary plight of South Tyrol ensured that the play tended to be received as a celebration of that regional identity, its central motif of the village passion play with unforeseen historical consequences can stand alongside Ödön von Horváth’s petty bourgeois 'verpatzte Feste' [celebrations that go wrong], as an alternative and more self-reflexive counterpoint to the public celebrations of religious, political and cultural identities that proliferated in interwar Austria. ${ }^{41}$ It has its distinctive reference points in the Neo-Baroque idiom

\footnotetext{
${ }^{41}$ Wendelin Schmidt-Dengler, 'Von der Unfähigkeit zu feiern. Verpatzte Feste bei Horváth und seinen Zeitgenossen', Literatur und Kritik, 237/238 (September/October 1989), 314-23.
} 
favoured by Hofmannsthal and Mell, and in the local performance traditions that were maintained or revived in numerous Alpine villages and notably championed by Mell. ${ }^{42}$

However, the final version of Der Judas von Tirol suggests a more conciliatory approach towards Catholicism and Catholic festival culture. Produced at a time when Schönherr publicly claimed a sentimental attachment to the Alpine performance tradition, it brings his earlier work into line with the more conservative cultural and political climate of the 1930s, as well as with his later plays, Passionsspiel and Die Fahne weht. Premiered at the Burgtheater on Palm Sunday in 1934, the Passionsspiel makes relatively free with the biblical narrative, telling human stories around that of Jesus's suffering in quasi-Naturalistic fashion. It provoked considerable controversy, but nonetheless celebrates the Passion (and by extension Austria's Catholic heritage) without any form of metatheatrical framing that might invite critical reflection. ${ }^{43}$ In Die Fabne webt, Andreas Hofer is once again in hiding, and a Tyrolean village stages its traditional passion play, which 'goes wrong' with unforeseen consequences. Here, however, the short circuit between play and metaplay catalyzes resistance rather than betrayal, as the stubborn heroism of fictional Tyrolean

\footnotetext{
${ }^{42}$ Several examples of his enthusiasm can be found in Max Mell, Steirischer Lobgesang (Leipzig, 1939). 'Hirtenspiel in Kärnten' first appeared in 1922, in Neue Deutsche Beiträge, $1^{\text {st }}$ ser., 1 (1922), 159-70. The shortlived journal was edited by Hugo von Hofmannsthal.

${ }^{43}$ On the unconventionality of Schönherr's Passionsspiel, in Claus Gillmann, 'Das dramatische Werk Karl Schönherrs und seine Rezeption in Wien' (unpublished doctoral dissertation, University of Vienna, 1973), pp. 302-11. The Burgtheater production is discussed in Robert Pyrah, The Burgtheater and Austrian Identity. Theatre and Cultural Politics in Vienna, 1918-38 (London, 2007), pp. 45-46. Pyrah is, however, under the misapprehension that the Passionsspiel is a playwithin-a-play.
} 
rebel Peter Raitmair is mapped onto the Passion. ${ }^{44}$ In what is effectively Schönherr's 'Nachfolge Christi-Spiel', local patriotism is inseparable from a simple but heartfelt piety, and both are presented in an unambiguously affirmative manner.

${ }^{44}$ On Die Fahne weht, see Gillmann, 'Das dramatische Werk Karl Schönherrs', pp. 326-49 and Pyrah, The Burgtheater and Austrian Identity, pp. 46-48. 